\title{
Factors Preventing the Use of Alternative Transport Modes to the Car in Later Life
}

\author{
Carlo Luiu *(i), Miles Tight ${ }^{(\mathbb{D})}$ and Michael Burrow \\ School of Engineering, College of Engineering and Physical Sciences, University of Birmingham, \\ Birmingham B15 2TT, UK; M.R.Tight@bham.ac.uk (M.T.); M.P.Burrow@bham.ac.uk (M.B.) \\ * Correspondence: c.luiu.1@pgr.bham.ac.uk
}

Received: 27 April 2018; Accepted: 7 June 2018; Published: 13 June 2018

\begin{abstract}
Recent research related to transport gerontology argues that the autonomy, flexibility and independence provided by the car are fundamental in fulfilling travel needs in later life. Statistics show that in the western world the car is the most used mode of travel among the older population. Despite the importance of promoting transport policies to incentivize people to switch to more sustainable forms of transportation, alternatives to the car are still underused by older people. The aim of this scoping review is to analyze the transport barriers affecting the use of alternative modes to the car in later life. The paper investigates how issues related to personal security, health impairments, service provision, affordability, comfort, attitude, built environment, information and awareness of all transport modes influence modal choice. The analysis of the literature shows that despite the benefits provided by public transport, flexible transport services, taxis, walking and cycling, there are still several factors that negatively affect the use of these modes. The paper concludes by reflecting on potential solutions that might help to create a transport system less reliant on the car and which is able to meet the mobility needs of the older population.
\end{abstract}

Keywords: older people; transport barriers; mobility needs; quality of life; transport gerontology; scoping review

\section{Introduction}

The implications of the ageing of the population has been the focus of numerous recent studies due to the considerable demographic changes forecast for the coming decades [1,2]. It has been suggested that successful ageing is associated with a good quality of life and that mobility is an important aspect of this [3-6]. Indeed, out-of-home mobility is necessary not only to enable independence, but it also allows older people to maintain a healthy and active life and to take part in social, cultural and leisure activities [6]. The ability to use transportation is also considered one of the seven criteria for building the Instrumental Activities of Daily Living (IADL), an assessment method designed to understand how independent older people are in everyday life [7].

The older population is characterized by being a heterogeneous group [2,8]. An approach used in transport studies is to analyze this heterogeneity by segmenting older adults [9]. Segmentations in the transport field are diverse and based upon different variable sets, for example: socio-demographics [10]; socio-demographics, infrastructure, mobility-related attitudes [11]; variety and activity frequency [12]; access to the car and use of different transport modes [13]; trip frequency, variety of transport options, activity variety, and mobility satisfaction [14] and; mobility specific attitudes and car availability [15]. As Table 1 shows, mobility segmentations of older people are various, but usually associated with attitudes to transport modes and level of mobility. In their review of the literature about mobility segmentation in later life, both Haustein, Siren, Framke, Bell, Pokriefke, Alauzet, Marin-Lamellet, Armoogum and O'Neill [9] and Haustein and Siren [16] concluded that older people can be grouped 
into four main segments: (1) Affluent mobile drivers (predominant car users with high mobility engagement); (2) Car dependent seniors (predominant car users with low mobility engagement); (3) Mobile multi-modal seniors (use of all modes with high/medium mobility engagement) and (4) transport service dependent seniors (walking, public transport users and car passenger with low mobility engagement).

Table 1. Overview of different segmentations of older people and the relation between the resulting segments (adapted from [9]).

\begin{tabular}{|c|c|c|c|c|c|}
\hline & $\begin{array}{l}\text { Aigner-Breuss } \\
\text { et al., } 2010 \text { [13] }\end{array}$ & Hildebrand, 2003 [10] & Bell et al., 2010 [17] & Haustein et al., 2008 [15] & Haustein, 2012 [11] \\
\hline Variables & Car Use & $\begin{array}{l}\text { Socio-Demographic } \\
\text { and Household } \\
\text { Variables } \\
\text { (e.g., Driving License, } \\
\text { Head of the } \\
\text { Household) }\end{array}$ & $\begin{array}{c}\text { Health, Household } \\
\text { Structure, } \\
\text { Occupation }\end{array}$ & $\begin{array}{l}\text { Socio-Demographic, } \\
\text { Infrastructure, } \\
\text { Mobility-Related } \\
\text { Attitudes }\end{array}$ & $\begin{array}{c}\text { Socio-Demographic, } \\
\text { Infrastructure, } \\
\text { Mobility-Related } \\
\text { Attitudes }\end{array}$ \\
\hline $\begin{array}{l}\text { Car-oriented but } \\
\text { restricted in } \\
\text { mobility }\end{array}$ & \multirow{3}{*}{$\begin{array}{l}\text { Older people } \\
\text { who } \\
\text { predominantly } \\
\text { use car }\end{array}$} & Disabled drivers & & Restricted Mobiles & Captive car user \\
\hline Car-oriented & & Affluent Males & \multirow{2}{*}{ Mobile person } & \multirow{2}{*}{ Mobile car-oriented } & \multirow{2}{*}{ Affluent Mobiles } \\
\hline highly mobile & & Mobile Widows & & & \\
\hline $\begin{array}{c}\text { Open to all } \\
\text { transport modes }\end{array}$ & $\begin{array}{c}\text { Selective car } \\
\text { users }\end{array}$ & & $\begin{array}{l}\text { Slightly restricted } \\
\text { mobiles }\end{array}$ & Self-determined mobiles & $\begin{array}{l}\text { Self-determined } \\
\text { Mobiles }\end{array}$ \\
\hline $\begin{array}{l}\text { Captive public } \\
\text { transport users }\end{array}$ & $\begin{array}{l}\text { Older people } \\
\text { w/o access to a } \\
\text { private car }\end{array}$ & Mobility impaired & $\begin{array}{l}\text { Highly restricted } \\
\text { mobiles }\end{array}$ & Pragmatic PT-oriented & $\begin{array}{l}\text { Captive Public } \\
\text { Transport Users }\end{array}$ \\
\hline
\end{tabular}

As shown in Table 1, studies of transport gerontology attribute a significant importance to the role that access to the car has in later life. The car meets the majority of transport needs of older people by fulfilling most of the conditions that Metz [6] describes as defining mobility (access to desired places; psychological benefits of travel; benefits of physical movement; maintaining social networks and maintaining potential travel). It also provides autonomy, flexibility and independence [18], it is available at any hour and allows desired destinations to be reached conveniently [19]. Moreover, it can compensate for health impairments, allowing older people to be independent when undertaking daily activities [20]. Various studies have found access to the car necessary to fulfil travel needs in later life [20-27]. In these studies, older people who had stopped driving or who had never previously driven were found to report more unmet travel needs compared to those still driving. Most reported unmet travel needs were those associated with social and leisure activities, such as visiting friends or family, or travelling to the countryside [26]. In general, older people without car access were found to have a lower quality of life [5] and were considered "among the least mobile, among those most at risk for social isolation and inadequate service availability" [28]. The importance of the car is also confirmed by studies on driving cessation. Stopping driving can be perceived as a loss of independence $[19,29]$ and is strongly associated with symptoms of depression [30,31]. Furthermore, the car remains the preferred mode of transport once driving has been given up, since asking for a lift from family or friends is considered the first option for people who cannot drive [18,19,32-36].

It is commonly presumed that as people age they are more likely to face mobility problems, will stop driving and consequently will switch to using public transport services or special demand-responsive transport services [37]. This perception may be based on patterns which show that older people rely more on public transport compared to younger people. However, there is no published evidence to support this assertion [38]. Contrary to this, data show that as the size of the older population increases, so does the percentage of car license holders in the older population. For example, statistics show that by 2030 approximately $90 \%$ of the British male population aged between $60-69$, and approximately $80 \%$ of those aged 70 and over will be license holders. For the British female population, the corresponding percentages are $80 \%$ and 50\% [39] (Figure 1). 

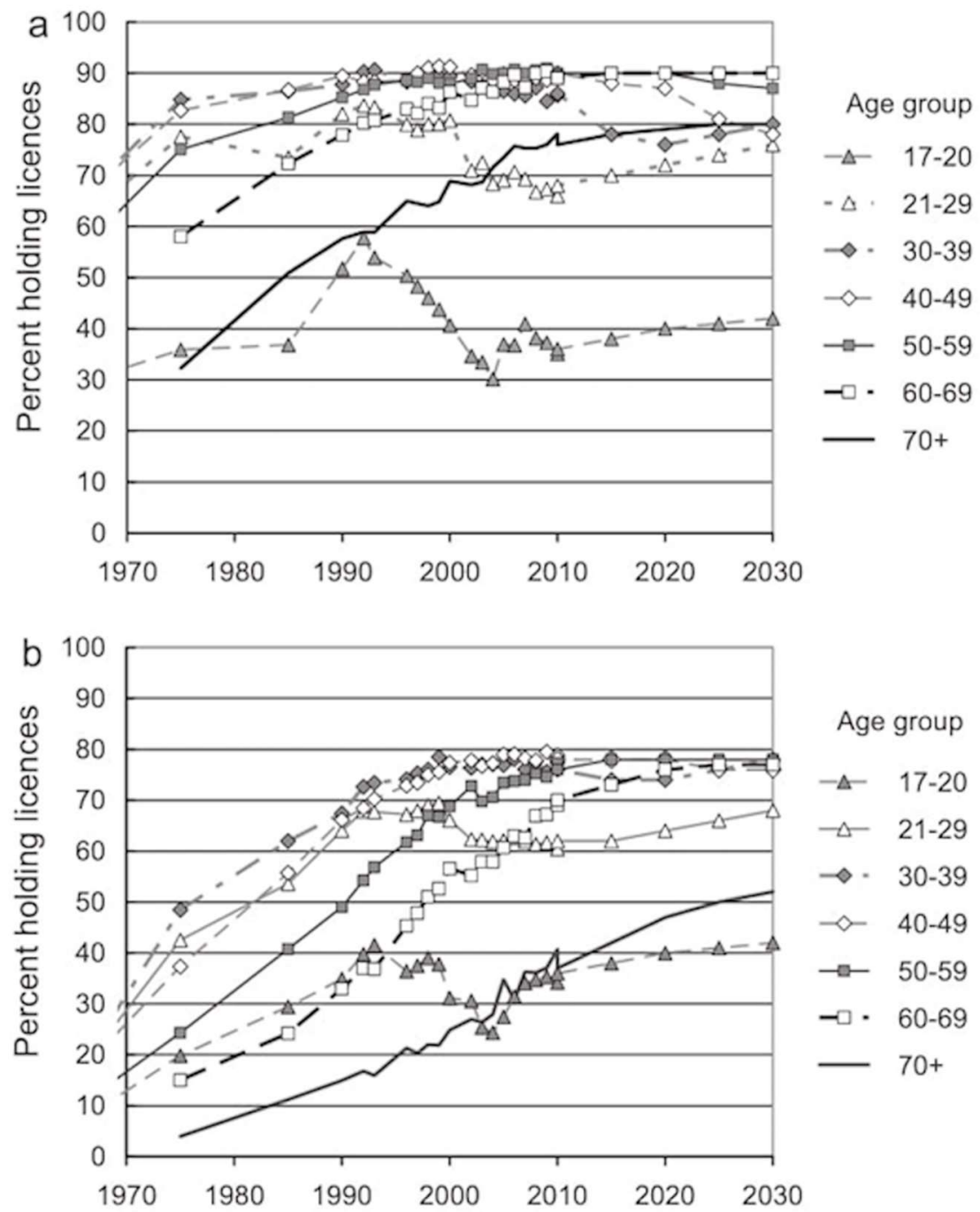

Figure 1. (a) Forecast percent of men holding car driving licenses in Great Britain; (b) Forecast percent of women holding car driving licenses in Great Britain [39].

Therefore, it may be postulated that the ageing population in developed countries is becoming increasingly car dependent and less likely to use alternative transport [38]. This reliance seems to be particularly evident in suburban [34,40] and rural environments [32,35,41]. Tacken [42] highlighted that "mobility behavior follows the general rule that people stay as long as possible with the type of behavior they are used to". Considering these facts, it seems that car dependence trends among older people are unlikely to decrease [43] for the foreseeable future.

Brake [44] argues that successful transport services are reliant upon passenger acceptance. Therefore, this review explores the transport barriers to passenger acceptance of alternative modes to the car in later life. The focus of the investigation is on understanding why public transport services, flexible transport services (FTS), taxis, walking and cycling are often not considered by older people as valid solutions to meet their mobility needs. The review also explores potential solutions to these barriers.

\section{Methodology}

A scoping review approach was used to identify the existing literature about the factors preventing the use of alternative transport modes to the car during later life. This type of review is designed to capture the breadth and depth of available evidence on a given topic by mapping, examining 
and summarizing the extent of research activity, findings and gaps [45,46]. This study followed the methodological framework developed by Arksey and O'Malley [46] for conducting a scoping review.

The following question was developed to guide the review process: Which are the main factors in terms of transport barriers preventing the use of alternatives modes to the car among the older population? The search strategy focused on the investigation of peer-reviewed journal articles as well as grey literature (e.g., reports, books and conference papers) and comprised of three main stages. The first consisted of defining the search terms. These were identified according to three different layers associated with transport modes, population and barriers. Transport modes related to public transport, FTS, taxis, and walking and cycling were searched together with terms associated with synonyms and alternative spellings for older people and barriers by using Boolean operators to generate standard database search strings. The full list of the database search terms string is shown in Table 2.

Table 2. Key terms for search strategy.

\begin{tabular}{cl}
\hline Concept & \multicolumn{1}{c}{ Search Term } \\
\hline \multirow{3}{*}{ Transport modes } & $\begin{array}{l}\text { public transport* OR public transit OR bus OR train OR tram OR tube OR taxi OR } \\
\text { walk* OR cycl* OR bicycle OR bike OR mobility scooter OR flexible transport service } \\
\text { OR door-to-door service OR dial-a-ride service OR community transport* OR minicab } \\
\text { OR minibus OR shared taxi OR taxi-buses OR demand responsive transport* OR } \\
\text { special transport* service OR paratransit }\end{array}$ \\
\hline Population & $\begin{array}{l}\text { AND old* people OR old* population OR old* adults OR senior* OR elder* OR elder* } \\
\text { people OR aged people OR ageing }\end{array}$ \\
\hline Barrier & AND barrier OR transport* barrier OR issue \\
\hline
\end{tabular}

Thereafter, the identified terms were searched in four electronic databases, namely: Scopus, Web of Science, Transportation Research International Documentation (TRID) and PubMed. The identified databases were selected due to their comprehensive coverage and acceptability by the research community. The search strategy was restricted to studies published after 1990 and written in the English language. The database search returned a total of 10258 studies. An assessment of relevance was undertaken to filter and identify the studies for the review, as shown in Figure 2. The process consisted of firstly removing duplicates (excluded $n=6311$ ), then studies were analyzed by title (excluded $n=2566$ ), abstract (excluded $n=967$ ) and text (excluded $n=360$ ). Studies not related to the transport, geography, planning, social science and gerontology fields; those focused only on aviation or naval transport, medical conditions or clinical issues (e.g., specific disease, home care, nursing, dental care or physical rehabilitation); those focused on young people and those for which the full document could not be retrieved were excluded during the refining process.

The search process produced a set of 54 studies for further data extraction and synthesis. It comprised of journal articles $(n=42)$; conference papers $(n=1)$; book chapters $(n=2)$, reports produced by a governmental or affiliated organization $(n=2)$; reports produced by a research institution $(n=3)$; reports produced by consulting agency $(n=4)$. The data from the selected studies were then extracted and charted, as shown in Table 3. The table describes for each study the year of publication, type of document, transport modes investigated and related barriers, in addition to the geographical context when applicable. Finally, the identified studies for the review were summarized according to the charted data. A content analysis was developed for each transport mode and related information was organized thematically based on type of identified transport barriers, namely: personal security, health impairments, service provision, affordability, comfort, attitude, built environment, information and awareness. 


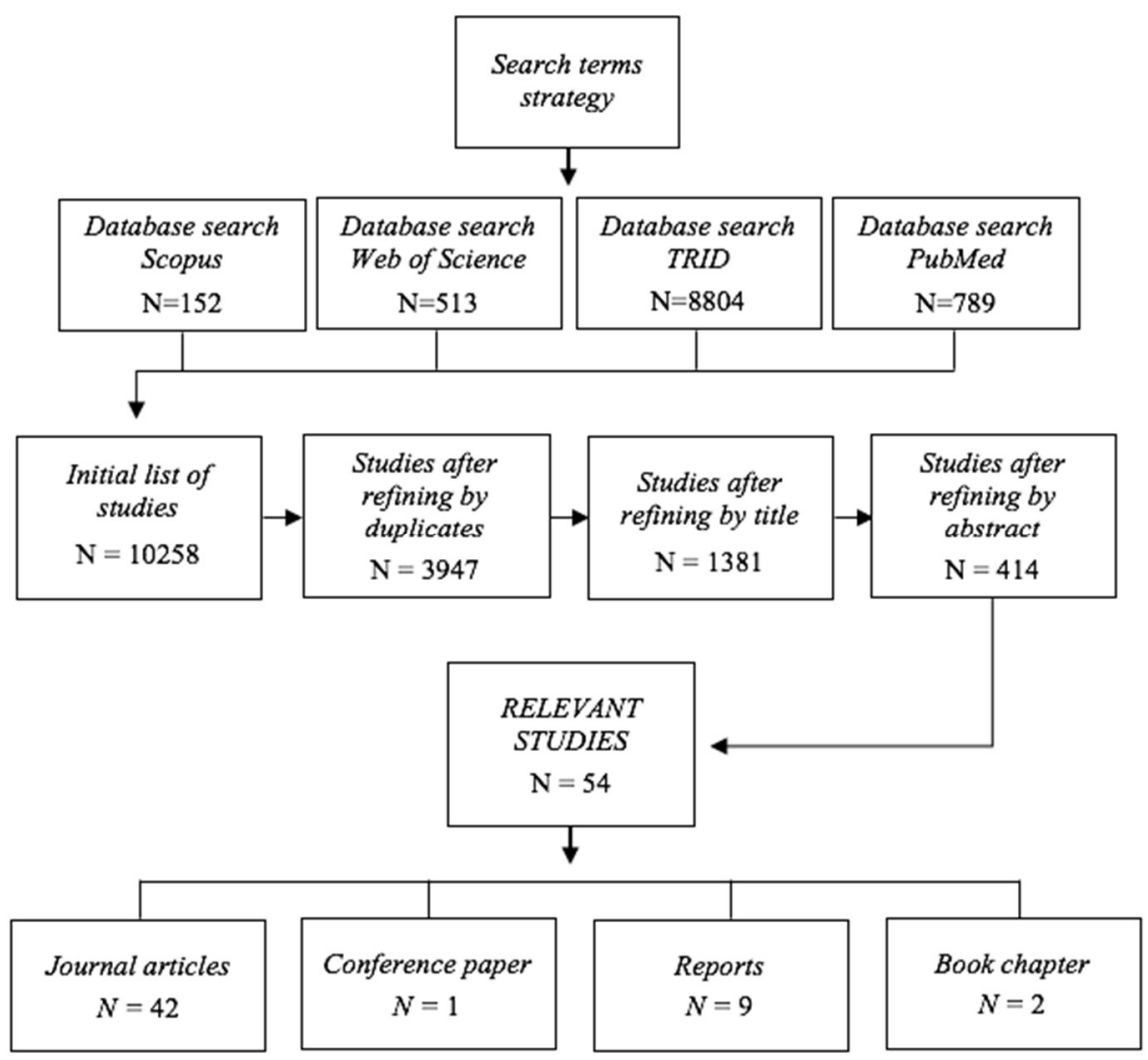

Figure 2. Search strategy process.

Table 3. Overview of selected studies and related barriers investigated.

\begin{tabular}{|c|c|c|c|c|c|c|}
\hline Author(s) & Year & Reference & $\begin{array}{l}\text { Type of } \\
\text { Outlet }\end{array}$ & $\begin{array}{c}\text { Transport } \\
\text { Modes }\end{array}$ & Barriers & Study Location \\
\hline Odufuwa & 2006 & [47] & Journal & $\mathrm{PT}$ & $\mathrm{AFF} / \mathrm{SP} / \mathrm{COM} / \mathrm{H} / \mathrm{SAF}$ & Nigeria \\
\hline Davey & 2007 & [19] & Journal & $\begin{array}{l}\text { PT } \\
\text { Taxi } \\
\text { FTS }\end{array}$ & $\begin{array}{c}\mathrm{SP} / \mathrm{H} \\
\mathrm{SP} / \mathrm{AFF} \\
\mathrm{INFO}\end{array}$ & New Zealand \\
\hline Glasgow and Blakely & 2008 & [18] & Journal & $\begin{array}{l}\text { PT } \\
\text { FTS } \\
\text { Taxi }\end{array}$ & $\begin{array}{c}\mathrm{SP} / \mathrm{H} \\
\mathrm{SP} / \mathrm{ATT} \\
\mathrm{SP} / \mathrm{AFF}\end{array}$ & U.S.A. \\
\hline Amosun et al. & 2009 & {$[48]$} & Journal & Walking & $\mathrm{BE}$ & South Africa \\
\hline Rosenbloom & 2009 & [38] & Journal & $\begin{array}{c}\text { PT } \\
\text { FTS } \\
\text { Walking }\end{array}$ & $\begin{array}{c}\mathrm{SP} / \mathrm{H} / \mathrm{COM} \\
\mathrm{SP} \\
\mathrm{BE} / \mathrm{SAF}\end{array}$ & U.S.A. \\
\hline Su and Bell & 2009 & [49] & Journal & $\begin{array}{l}\text { PT } \\
\text { FTS }\end{array}$ & $\begin{array}{c}\mathrm{SP} / \mathrm{H} / \mathrm{INFO} \\
\text { INFO }\end{array}$ & United Kingdom \\
\hline Wretstrand et al. & 2009 & [50] & Journal & PT & $\mathrm{SP} / \mathrm{H} / \mathrm{SAF} / \mathrm{INFO}$ & Sweden \\
\hline Broome et al. & 2010 & [51] & Journal & PT & $\mathrm{SP} / \mathrm{H} / \mathrm{SAF} / \mathrm{COM} / \mathrm{INFO}$ & Australia \\
\hline Broome et al. & 2010 & [52] & Journal & PT & $\mathrm{SP} / \mathrm{H} / \mathrm{SAF} / \mathrm{COM} / \mathrm{INFO}$ & Australia \\
\hline Chang and $\mathrm{Wu}$ & 2010 & [53] & Journal & PT & $\mathrm{H} / \mathrm{INFO}$ & Taiwan \\
\hline Mattson & 2010 & [54] & Journal & $\mathrm{PT}$ & $\mathrm{SP} / \mathrm{COM} / \mathrm{INFO}$ & U.S.A. \\
\hline Rantakokko et al. & 2010 & [55] & Journal & Walking & $\mathrm{H} / \mathrm{BE} / \mathrm{SAF}$ & Finland \\
\hline Risser et al. & 2010 & [56] & Journal & $\begin{array}{c}\text { PT } \\
\text { Walking }\end{array}$ & $\begin{array}{c}\text { SAF/COM } \\
\text { BE }\end{array}$ & $\mathrm{N} / \mathrm{A}$ \\
\hline Broome et al. & 2011 & [57] & Journal & PT & INFO & Australia \\
\hline $\begin{array}{l}\text { Hanson and } \\
\text { Hildebrand }\end{array}$ & 2011 & [35] & Journal & $\mathrm{PT}$ & SP & Canada \\
\hline
\end{tabular}


Table 3. Cont

\begin{tabular}{|c|c|c|c|c|c|c|}
\hline Author(s) & Year & Reference & $\begin{array}{l}\text { Type of } \\
\text { Outlet }\end{array}$ & $\begin{array}{l}\text { Transport } \\
\text { Modes }\end{array}$ & Barriers & Study Location \\
\hline Buys et al. & 2012 & [43] & Journal & $\mathrm{PT}$ & $\mathrm{SP} / \mathrm{SAF} / \mathrm{COM} / \mathrm{INFO}$ & Australia \\
\hline Zeitler and Buys & 2015 & [34] & Journal & PT & $\mathrm{SP} / \mathrm{INFO}$ & Australia \\
\hline Vine et al. & 2012 & {$[58]$} & Journal & $\begin{array}{c}\text { PT } \\
\text { Walking }\end{array}$ & $\begin{array}{c}\mathrm{SP} / \mathrm{H} / \mathrm{COM} / \mathrm{INFO} \\
\mathrm{BE} / \mathrm{SAF}\end{array}$ & Australia \\
\hline Ahern and Hine & 2012 & [41] & Journal & $\begin{array}{l}\text { PT } \\
\text { FTS }\end{array}$ & $\begin{array}{c}\text { SP } \\
\text { ATT }\end{array}$ & $\begin{array}{l}\text { Rep. of Ireland and } \\
\text { Northern Ireland }\end{array}$ \\
\hline Brake et al. & 2004 & [59] & Journal & FTS & SP/INFO & $\mathrm{N} / \mathrm{A}$ \\
\hline Mulley et al. & 2012 & [60] & Journal & FTS & SP/ATT & $\mathrm{N} / \mathrm{A}$ \\
\hline Broome et al. & 2012 & [61] & Journal & FTS & $\mathrm{SP} / \mathrm{INFO}$ & Australia \\
\hline Asher et al. & 2012 & [62] & Journal & Walking & $\mathrm{BE}$ & United Kingdom \\
\hline Broome et al. & 2013 & [63] & Journal & PT & $\mathrm{SP} / \mathrm{H} / \mathrm{COM} / \mathrm{INFO}$ & Australia \\
\hline Hjorthol & 2013 & [64] & Journal & $\begin{array}{c}\text { PT } \\
\text { Walking }\end{array}$ & $\begin{array}{c}\mathrm{H} / \mathrm{COM} \\
\mathrm{BE}\end{array}$ & Norway \\
\hline Ward et al. & 2013 & [33] & Journal & $\begin{array}{l}\text { PT } \\
\text { FTS }\end{array}$ & $\begin{array}{c}\mathrm{SP} / \mathrm{H} \\
\mathrm{SP} / \mathrm{INFO}\end{array}$ & United Kingdom \\
\hline Daniels and Mulley & 2013 & [65] & Journal & FTS & INFO/ATT & Australia \\
\hline Zander et al. & 2013 & [66] & Journal & Cycling & $\mathrm{BE} / \mathrm{SAF}$ & Australia \\
\hline Eronen et al. & 2014 & [67] & Journal & Walking & $\mathrm{H} / \mathrm{BE} / \mathrm{SAF}$ & Finland \\
\hline Ipingbemi & 2014 & [68] & Journal & PT & $\mathrm{AFF} / \mathrm{SP} / \mathrm{COM} / \mathrm{H} / \mathrm{SAF}$ & Nigeria \\
\hline Kim et al. & 2014 & [23] & Journal & $\mathrm{PT}$ & $\mathrm{H} / \mathrm{INFO}$ & $\begin{array}{l}\text { The Republic of } \\
\text { Korea }\end{array}$ \\
\hline Olawole and Aloba & 2014 & [69] & Journal & $\mathrm{PT}$ & $\mathrm{AFF} / \mathrm{SP} / \mathrm{COM} / \mathrm{H} / \mathrm{SAF}$ & Nigeria \\
\hline Shiau \& Huang & 2014 & [70] & Journal & $\begin{array}{l}\text { PT } \\
\text { Taxi }\end{array}$ & $\begin{array}{l}\mathrm{COM} / \mathrm{SAF} \\
\mathrm{SP}\end{array}$ & Taiwan \\
\hline Chen et al. & 2015 & [71] & Journal & Walking & $\mathrm{BE}$ & Taiwan \\
\hline Shergold et al. & 2015 & [72] & Journal & PT & INFO & United Kingdom \\
\hline Mitra et al. & 2015 & [73] & Journal & Walking & $\mathrm{BE} / \mathrm{SAF}$ & Canada \\
\hline Winters et al. & 2015 & [74] & Journal & Cycling & SAF & Canada \\
\hline Loo and Tsui & 2016 & [75] & Journal & Walking & $\mathrm{BE}$ & Hong Kong \\
\hline Tournier et al. & 2016 & [76] & Journal & Walking & $\mathrm{H}$ & $\mathrm{N} / \mathrm{A}$ \\
\hline $\begin{array}{c}\text { Ramachadran and } \\
\text { D'Souza }\end{array}$ & 2016 & [77] & Journal & $\begin{array}{c}\mathrm{PT} \\
\text { Walking }\end{array}$ & $\begin{array}{l}\mathrm{H} / \mathrm{COM} \\
\mathrm{BE} / \mathrm{SAF}\end{array}$ & India \\
\hline Ryan et al. & 2016 & [78] & Journal & Cycling & $\mathrm{H} / \mathrm{BE} / \mathrm{SAF}$ & Sweden \\
\hline Wang et al. & 2016 & [79] & Journal & $\begin{array}{l}\text { Walking } \\
\text { Cycling }\end{array}$ & $\begin{array}{l}\mathrm{BE} / \mathrm{SAF} \\
\mathrm{BE} / \mathrm{SAF}\end{array}$ & $\mathrm{N} / \mathrm{A}$ \\
\hline Velasco et al. & 2015 & [80] & $\begin{array}{l}\text { Conference } \\
\text { paper }\end{array}$ & Cycling & $\mathrm{BE} / \mathrm{SAF}$ & Spain \\
\hline WS Atkins & 2000 & [81] & Report & $\begin{array}{c}\text { PT } \\
\text { FTS } \\
\text { Taxi } \\
\text { Walking }\end{array}$ & $\begin{array}{c}\mathrm{SP} / \mathrm{H} / \mathrm{COM} \\
\mathrm{SP} \\
\mathrm{SP} / \mathrm{AFF} \\
\mathrm{BE} / \mathrm{SAF}\end{array}$ & United Kingdom \\
\hline OECD & 2001 & [2] & Report & $\begin{array}{c}\text { PT } \\
\text { Walking } \\
\text { Cycling }\end{array}$ & $\begin{array}{c}\mathrm{SP} / \mathrm{H} / \mathrm{COM} / \mathrm{INFO} \\
\mathrm{H} / \mathrm{BE} / \mathrm{SAF} \\
\mathrm{BE} / \mathrm{SAF}\end{array}$ & $\mathrm{N} / \mathrm{A}$ \\
\hline Gilhooly et al. & 2002 & [5] & Report & $\mathrm{PT}$ & SP/SAF/COM/INFO & United Kingdom \\
\hline Harris and Tapsas & 2006 & [82] & Report & Taxi & $\mathrm{SP} / \mathrm{AFF}$ & Australia \\
\hline Knight et al. & 2007 & [83] & Report & $\begin{array}{c}\text { PT } \\
\text { FTS } \\
\text { Taxi } \\
\text { Walking } \\
\text { Cycling }\end{array}$ & $\begin{array}{c}\mathrm{SP} / \mathrm{H} / \mathrm{SAF} / \mathrm{COM} \\
\mathrm{SP} / \mathrm{ATT} \\
\mathrm{AFF} \\
\mathrm{H} / \mathrm{SAF} \\
\mathrm{SAF}\end{array}$ & United Kingdom \\
\hline
\end{tabular}


Table 3. Cont

\begin{tabular}{ccccccc}
\hline Author(s) & Year & Reference & $\begin{array}{c}\text { Type of } \\
\text { Outlet }\end{array}$ & $\begin{array}{c}\text { Transport } \\
\text { Modes }\end{array}$ & Barriers & Study Location \\
\hline Fiedler & 2007 & {$[84]$} & Report & PT & SP/SAF/COM & N/A \\
\hline Peck & 2010 & {$[85]$} & Report & PT & SP/H/SAF/COM/INFO & U.S.A. \\
\hline Mattson & 2010 & {$[54]$} & Report & PT & SP/INFO & U.S.A. \\
\hline NCST & 2011 & {$[86]$} & Report & Taxi & SP/AFF & U.S.A. \\
\hline Mindell et al. & 2011 & {$[87]$} & $\begin{array}{c}\text { Book } \\
\text { chapter }\end{array}$ & Walking & BE/SAF & United Kingdom \\
\hline $\begin{array}{c}\text { Aceves-Gonzalez et } \\
\text { al. }\end{array}$ & 2016 & {$[88]$} & $\begin{array}{c}\text { Book } \\
\text { chapter }\end{array}$ & PT & SAF/SP/COM & Mexico \\
\hline
\end{tabular}

Legend: PT: Public transport; FTS: Flexible transport service; ATT: Attitude; COM: Comfort; H: Health; INFO: Information and awareness; SAF: Safety and personal security; SP: Service provision; BE: Built environment; AFF: Affordability.

\section{Results}

Despite transport usage depending on several factors (e.g., access to transport resources, socio-economic characteristics and health conditions), almost half of the journeys older people undertake in several European countries are made by car $[2,17,89]$ (Figure 3). The percentage is even higher in Australia at $70 \%$ [2], and in the USA, with more than $80 \%$, both as a driver and passenger [40]. A lack of valid alternative transport modes to the car is often reported by older people as one of the main reasons for car reliance. Despite the importance of promoting transport policies to incentivize the switch from private vehicle to more sustainable forms of transportation, alternatives to the car are still underused by the older population.

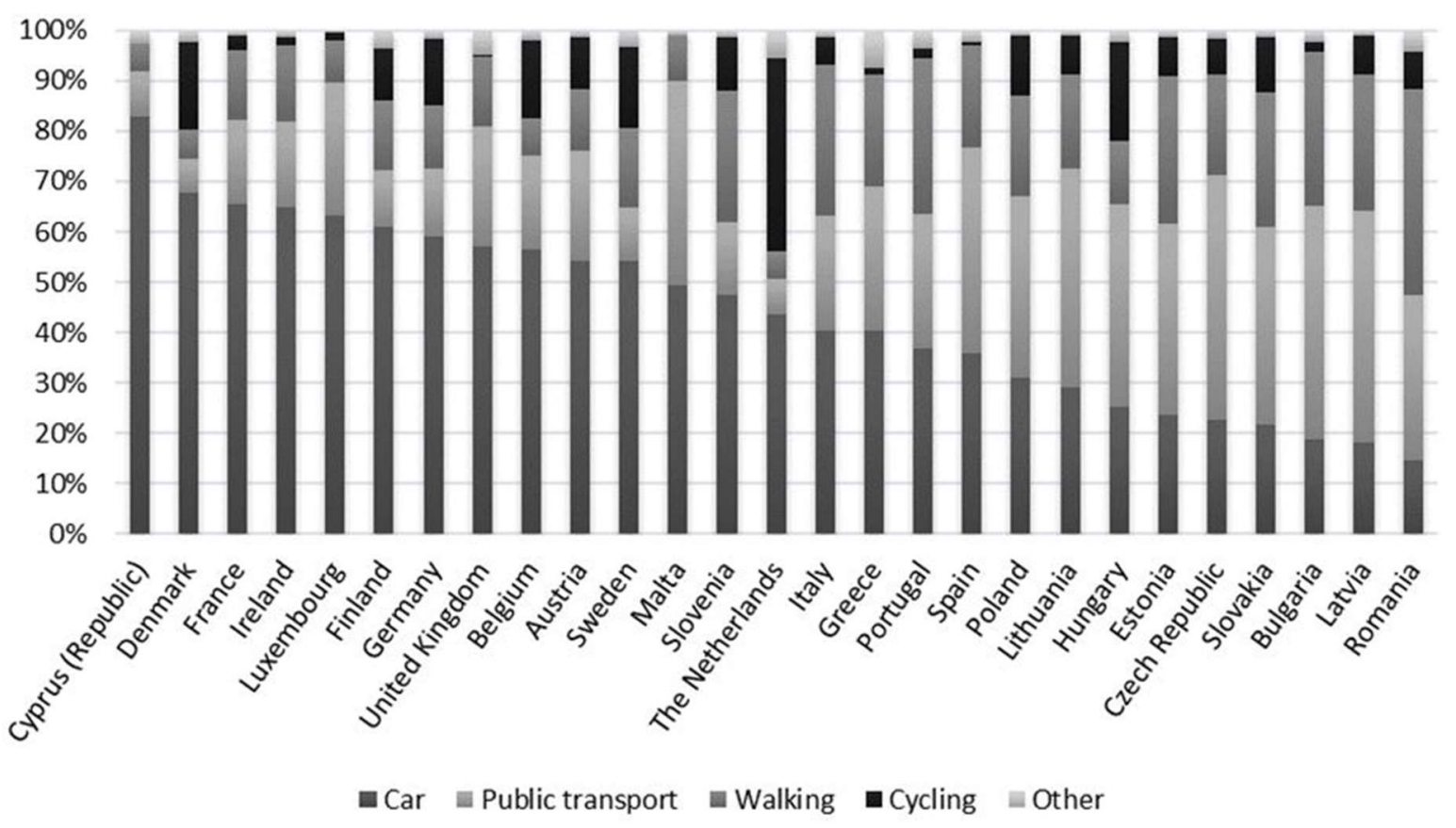

Figure 3. Mode share by country-People aged 55 years and above [89].

The following sections explain the main factors affecting the use of public transport services, FTS, taxis, walking and cycling among older people identified within the literature. More specifically, transport modes have been analyzed according to built environment, health, personal security, service provision, affordability, comfort, attitude, information and awareness issues. Table 4 summarizes the main issues for each identified barrier. It is important to highlight that when analyzing the mobility of 
older people, it is always necessary to consider the heterogeneity in terms of demographic background characteristics, health conditions and transport resources they have, and therefore not all older people might be affected by these barriers.

Table 4. Overview of identified barriers per transport mode.

\begin{tabular}{|c|c|c|}
\hline Barrier & Transport Mode & Issue \\
\hline \multirow{3}{*}{ Service provision } & Public transport & $\begin{array}{l}\text { Unsuitable routes and timetable } \\
\text { Poor service provision during off-peak time } \\
\text { Poor punctuality and connectivity with other buses or modes } \\
\text { Stop/station location } \\
\text { Awaiting times }\end{array}$ \\
\hline & FTS & $\begin{array}{l}\text { Booking issues } \\
\text { Lack of spontaneity for leisure activities }\end{array}$ \\
\hline & Taxi & $\begin{array}{l}\text { Lack of provision in specific contexts (e.g., rural) } \\
\text { Awaiting times } \\
\text { Taxi driver behavior }\end{array}$ \\
\hline \multirow[t]{2}{*}{ Health } & Public transport & $\begin{array}{l}\text { Boarding operation } \\
\text { Standing of moving bus } \\
\text { Walking distance to/from stop/station }\end{array}$ \\
\hline & Walking and Cycling & Risk of falling due to sensory/cognitive/physical impairment \\
\hline \multirow{2}{*}{$\begin{array}{l}\text { Safety and personal } \\
\text { security }\end{array}$} & Public transport & $\begin{array}{l}\text { Driver/operators' behavior } \\
\text { Other passengers' behavior } \\
\text { Overcrowded modes }\end{array}$ \\
\hline & Walking and Cycling & $\begin{array}{l}\text { Travelling at particular times due to inadequate lighting and } \\
\text { users behavior } \\
\text { Conflict with road users } \\
\text { Conflict cyclists-pedestrian in shared environment }\end{array}$ \\
\hline Comfort & Public transport & $\begin{array}{l}\text { Unsuitable bus shelter } \\
\text { Lack of toilet facilities on buses } \\
\text { Personal space and overcrowding conditions }\end{array}$ \\
\hline \multirow[t]{2}{*}{$\begin{array}{l}\text { Information and } \\
\text { awareness }\end{array}$} & Public transport & $\begin{array}{l}\text { Ticketing options } \\
\text { Understanding timetables and maps } \\
\text { Understanding directions of buses } \\
\text { Identification of approaching buses } \\
\text { Lack of familiarity with services }\end{array}$ \\
\hline & FTS & $\begin{array}{l}\text { Confusion about available schemes } \\
\text { Confusion about service provision } \\
\text { Lack of awareness about available services }\end{array}$ \\
\hline Attitude & FTS & $\begin{array}{l}\text { Stigma of specialized mode for impaired/disadvantaged } \\
\text { people }\end{array}$ \\
\hline \multirow[t]{2}{*}{ Affordability } & Public transport & $\begin{array}{l}\text { Concessionary fares outside municipal boundaries } \\
\text { High fares when no concessionary schemes are provided }\end{array}$ \\
\hline & Taxi & High fares \\
\hline Built environment & Walking and Cycling & $\begin{array}{l}\text { Crossing street operations } \\
\text { Poor design and quality of walking-cycling } \\
\text { infrastructure/environment } \\
\text { Presence of obstacles along the pathways }\end{array}$ \\
\hline
\end{tabular}

\subsection{Public Transport}

Public transport has been advocated as a low cost and low emissions alternative to the car, allowing passengers to avoid the stress associated with driving in congested traffic, to enjoy interaction with other people and to relax by reading, listening to music or by admiring the passing scenery 
while travelling [84,90-92]. However, public transport is perceived by older people as unresponsive to their travel needs $[56,93]$. The transport barriers affecting public transport usage among the older population can be grouped into six main categories: (1) reliability and availability of service provision; (2) health and mobility issues; (3) comfort; (4) personal safety; (5) information and awareness and (6) affordability.

Reliability and availability of service provision significantly affect modal choice. Unsuitable routes, timetables and scheduling are one of the most reported issues among public transport usage by older adults. Older people seek more flexibility for their trips than is provided for by fixed-route services [8]. Moreover, while rail-based services tend to be provided mainly on corridors of high-demand, road-based services tend to be affected by the so-called vicious cycles of public transport decline $[94,95]$. In cases of low demand, service providers tend to reduce frequency of provision in order to reduce costs. As a consequence, this might lead to a reduction of customers since some might reduce their usage or change transport options by preferring alternative modes. Therefore, this decline in demand can generate an additional decrease in frequency, which results in only captive customers using the service $[96,97]$. These cycles usually affect the most the weakest members of society, such as older and younger people, as well as disabled and low income earners, which are deprived of access to services and goods [94].

Serious trips [19], such as to medical appointments, are usually well-served by public transport, although they might be problematic in rural areas, due to inconvenient schedules and infrequent services [98]. Moreover, older people report dissatisfaction with public transport services for discretionary trips. Indeed, spontaneous travel for leisure, social and shopping activities is often unachievable $[19,99,100]$. Several studies have shown that older people have more time to spend than younger people and to some extent they can adjust their schedules around public transport availability $[49,101]$. Nonetheless, public transport services are considered unreliable due to lack of provision during off-peak times (e.g., weekend or holidays). Moreover, older people report dissatisfaction with the locations of stops, punctuality and waiting times and poor connectivity with other buses and/or transport modes $[5,41,43,47,49,51,54,63,68,69,81,84]$. This was found particularly valid for suburban or rural areas [18,35,41].

Public transport usage is particularly influenced by the health and mobility problems faced by older people, since the ageing process is associated with a variety of changes in mobility and ability. The main problems identified by the older population are linked to boarding and alighting from vehicles [88]. The ability to get on and off, as well as sometimes having to stand, are seen as key reasons for the lack of public transport usage $[23,47,50,51,53,63,68,69,77]$. Despite improvements to accessibility including the introduction of low-floor buses, there are a variety of obstacles that hinder the less mobile. These include cycle ways that can conflict with the pedestrian environment at bus stops, the narrowness of bus entrances, the presence of many buses at the same time and the gap between the bus and the curb [52,102]. Similarly, keeping balance while standing, particularly during acceleration and deceleration operations, can be physically challenging and increase the risk of falling when the transport mode is moving [53]. Bus stop density and locations also affect mobility problems. Inappropriate locations as well as the distance of stops from both home and destination may require an amount of walking that could deter older people from using public transport [2,19,23,47,49-52,64,81,85].

Older adults are especially sensitive about safety and security, particularly when travelling at night or at peak-times when buses and trains are likely to be less full, when travelling alone or due to the presence or behavior of other passengers $[5,47,52,56,68,85]$. An additional element, often underrated in transport research, is driver behavior [88]. Unfriendly and unhelpful drivers, who do not stop close to the curb, wait until passengers are seated prior to pulling away, drive erratically, fail to lower the bus during entry and exit operations and fail to provide assistance and information to passengers, are often reported by the older population as a safety concern $[5,43,47,51,68-70,84,88]$. 
Comfort also plays an important role. Poor vehicular design leading to overcrowding as well as lack of personal space, toilet facilities, room for heavy shopping and amount and position of handrails are frequently mentioned as factors affecting comfort $[5,43,51,52,56,58,68,77,84,85,103]$. Similarly, lack of or unsuitable bus shelters that do not provide adequate seating and shelter from adverse weather conditions at all times are factors affecting public transport usage [51,52,54,68-70,85].

As highlighted by Fiedler [84], accessibility to public transport is not only a matter of physical access to the service, but also access to information plays an important role in public transport usage. Lack or difficulties in getting information can prevent older users from using public transport. Principal issues in this sense include understanding ticketing options, timetables, maps and directions both at stops/station and on-board, in addition to finding bus stops and locations or recognizing approaching buses $[5,19,43,49-51,54,57,58,98,104]$. Lack of awareness and low familiarity with available transport modes also influence travel activities in later life [23], particularly in suburban [34,58] and rural areas [72] due to the high reliance on the car in such areas.

Finally, older people might experience affordability issues. Providing older people with concessionary schemes is a common policy in several countries, allowing them to travel for free or with discounted fares [105]. Nonetheless, some schemes might create affordability problems if provided only locally when travelling beyond the municipal boundaries [105] or if they are valid for some modes instead of others (e.g., tube vs buses in Seoul) [23]. Moreover, in contexts where concessionary schemes are not provided, cost of travel can be considerable. A few African studies $[68,69]$ have shown the significance of the cost of travelling with public transport due to high fares. This was found particularly valid for long distance journeys, since fares were based on modal choice and distance between origin and destination [69].

\subsection{FTS}

FTS are a form of public transport that is considered to be between a bus operating a regular service and the bespoke service offered by a taxi [59]. Thanks to the variety of modes and the flexibility in routes and timing, FTS have been advocated as a suitable alternative to private vehicles or mainstream public transport services and are seen as being better positioned to compete with the private transport market for passengers [106]. Modes that can be considered part of FTS are demand responsive transport (usually operated by small bus or minibus), shared taxis (known also as taxi-buses), community transport, dedicated services for disabled or mobility reduced people [106,107]. The main characteristics of FTS are improved accessibility and flexibility through door-to-door services and booking and routing facilities. Mulley, et al. [60] suggest that FTS can address several negative issues associated with conventional public transport, namely: spatial (due to lack of services), physical (inaccessible vehicles), time (lack of services at required times and journey take long time), information (users do not have proper information about journeys), economic (high costs of services) and cultural (cultural and attitudinal issues about usage of public transport services).

Due to their characteristics FTS have the potential to play a key role in social inclusion for specific mobility needs (e.g., older or disabled people) or where there are situations of low-demand provision, such as in suburbs and rural areas [108]. Moreover, the developments in Information and Communication Technology (ICT) and Intelligent Transport Systems (ITS) have generated significant opportunities for improvements in FTS provision [107]. However, improvements in technologies have not been followed by adequate enhancements in business models and organizational frameworks by service providers $[60,106]$. Despite the potential of this transport option, evidence shows that the FTS concept is still not well received and services provided are generally small-scale, fragmented and informal [106]. Barriers concerning the uptake of FTS can be associated with: (1) service provision; (2) information and awareness; (3) attitude.

Service provision issues are mainly associated with funding and costs to service users. Key issues are related to the high cost of service provision and the need for pump priming at an early stage. As Brake, et al. [109] highlight, FTS providers have shown significant difficulties in achieving financial 
sustainability over the long-term. FTS schemes usually receive public funding at launch, but due to the high costs of provision and low-demand from users, operators face problems to make sufficient revenue. This can lead to providers, once funding is finished, adapting their service to fixed routes and competing within the public transport market segment in order to achieve economic sustainability. The conditions required to receive funding may also be a cause of problems. For conventional public transport, the amount of subsidy is usually linked to the distance travelled by the service, which is difficult to forecast for FTS due to their flexible nature. As a consequence, to meet requirements in order to receive subsidies as a form of public transport, FTS are often forced to modify service provision, such as having fixed stops or fixed timing points [60]. Economic issues are not the only ones affecting FTS service provision. Both Glasgow and Blakely [18] and WS Atkins [81] found that the necessity of booking a journey with these type of services is a barrier to spontaneous trips. Some schemes also prioritize certain activities (e.g., medical trips), reducing the type of activities older people can undertake. Other schemes are designed to reach specific destinations, such as shopping or senior centers, or are provided for special occasions, but they are not available on a daily basis.

Information and awareness barriers concern the level of awareness FTS customers have about the service, with regards to available schemes and how these are provided. Confusion about the kind of FTS schemes available, when and where they travel is the most reported barrier in this sense $[19,33,49,61,83]$. The presence of more than one scheme or provision with different modes was also a factor increasing lack of awareness. Other examples include difficulties in understanding the concept of sharing any transport mode apart from buses (e.g., shared taxis) [65], or that FTS operate as conventional taxis due to the availability of booking services [110]. Furthermore, the high level of flexibility offered can lead to identification problems, since the more flexible the service is, the less visible it becomes to potential users. Absence of landmarks such as bus stops, a lack of an indicative logo, brand or promotional advertisements, may reduce awareness among users. Attitude barriers are related to culture and perception of FTS. Ahern and Hine [41] found that community transport in Irish rural areas was recognized as a "feminized" transport mode by male participants and therefore not used to meet their transport needs. While mainstream fixed-route public transport is regarded as normal, FTS can be perceived as a specialized service for impaired or generally disadvantaged people $[65,83]$. Glasgow and Blakely [18] found that the "young-older" (60-74 years old) reported low consideration of FTS due to the stigma associated with using these transport modes, while Kim [111] found a correlation between modal choice preference and age, with the older cohorts reporting more usage of FTS. Modifications to travel habits take time to build both patronage and acknowledgement of the service, therefore, customer attitudes are also affected by the time needed to change travel behavior $[60,65]$.

\subsection{Taxis}

Taxis are regarded as an important transport option for those people who do not have access to a car or are unable to use public transport due to health impairment [81]. Studies by Knight, Dixon, Warrener and Webster [83] and Oxley [112] found that older people using taxis were predominantly women, those with health impairments (especially mobility ones), those of low income, without access to a car and living in town. Taxis are seen as a fast and direct transport mode [9], available at any time [113] and are perceived as a safer mode compared to public transport [9,83], allowing older people to travel at any time of the day, such as during the night [83]. Moreover, taxis provide independence for those who have stopped driving and have to rely on family or friends for their journeys [43] and are not associated with the stigma of impairment unlike other modes (e.g., FTS) [113]. Nonetheless taxis are an underused transport mode among the older population. Two main reasons can be identified for this: service affordability and service provision.

Despite the convenience offered by taxis their usage is limited by affordability. Taxis have been found to be the most expensive transport mode in both the United Kingdom [81] and Australia [82], and this has been identified as the main disincentive to their use by older people [19]. Affordability 
problems emerged especially when taxis are compared with other transport modes. Taxis are perceived as more expensive than cars and public transport services, particularly when concessionary fare schemes for older people are available $[81,83]$. Therefore, taxis are not regarded as a valid option for regular transportation, but mainly as an occasional mode, or in some cases as a last resource $[18,83]$. Accordingly, taxi usage has been found to be mainly associated with trips to hospitals and medical appointments or for special occasions [41,83]. As a consequence, discretionary and spontaneous travel, as well as recreational journeys to the countryside, are considered "unacceptably extravagant" to do by taxi [19].

Service provision issues are generally related to the reliability and the availability of the service. Older people report issues about late arrival after booking [19], lack of information about the final cost of the journey and not being able to see the taxi meter [81]. The behavior of taxi drivers was also found to be a barrier to taxi usage, due to rudeness [18], dishonesty in route taking [81] and unwillingness to provide a service for short trips [82,86] or help with impaired people [70,86]. The nature of vehicles was also identified as an issue. Purpose-designed vehicles that guarantee a high level of accessibility are common in some countries, but rare elsewhere [86,112]. In the United Kingdom Hackney Carriages (black cabs) are wheelchair accessible by law, but this is not the case with most private hire taxi services [81]. Rural areas are characterized by a lack of service availability $[18,86]$. While small towns are usually covered by taxi services, older people living in rural villages report low taxi usage due to scarcity or no availability. Often, when there is a need to hire a taxi in a rural area, due to a lack of public transport provision, taxis have to come from the closest town, with significant additional cost involved [18].

\subsection{Walking and Cycling}

Walking and cycling are often promoted as a valid solution to mitigate the variety of problems raised by the modern car-oriented society. Indeed, both are green transport modes (no air and noise pollution), more affordable and reliable, and useful to reduce traffic congestion and parking problems $[78,114,115]$. For older people, walking and cycling are often regarded as more feasible and faster travel options to accomplish everyday activities compared to the car or public transport. This was found to be true especially for short journeys in denser cities or congested urban centers $[43,78,87]$. Both modes have the characteristic of being a transport option as well as a recreational activity and provide physical exercise, with consequent benefits to health and wellbeing $[66,74,78,87]$. However, walking and cycling are not always easy activities for older people to undertake. Very little research has been carried out on walking and cycling in later life from the transportation point of view, especially in terms of barriers affecting the use of these two modes, since researchers have focused mainly on safety of older drivers [76]. Nonetheless, three main issues can be identified: health, safety and the built environment.

It is recognized that mobility in later life is influenced by progressive changes to and deterioration of health [2]. Unlike other transport modes (e.g., car) that can compensate for health impairments [20], walking and cycling can be more directly affected by health problems. In their review, Tournier, Dommes and Cavallo [76] identified health barriers affecting older pedestrians according to sensory, cognitive and physical impairments. Sensory impairments are associated with the risk of falling, reduced perception of fixed and moving objects, problems in detecting approaching vehicles and difficulties in distinguishing vehicles from other aspects of the road environment. Cognitive impairments were found to affect multi-tasking processes and information, with consequent problems in spatial navigation and orientation (especially in new environments), learning new routes, increased time to make decisions to cross the street, slower walking speeds and higher risks of falling. Physical impairments are associated with changes in muscles and joints. Loss of strength in muscles can lead to reduced walking speed and risk of falling, while pain in joints was found to create problems in walking and climbing stairs. Other issues related to motor skills such as loss of agility, flexibility and endurance were associated with reductions in walking speed and in maintaining balance [2]. 
In general, risk and fear of falling were found to be the most reported barriers across the three categories analyzed. Older pedestrians tend to self-regulate their behavior due to the awareness of falling and report increased attention to their footsteps and the pavement, in addition to walking slower, especially in bad weather conditions [76]. Cognitive impairments were found to be more significant than a decline in physical condition for cycling cessation. Fear of not being able to quickly evaluate potential situations as well as a decline in reactions, memory and balance skills were identified as main health issues [78]. Finally, temporary stops due to injuries or illness was correlated with permanent cycling cessation, due to loss of familiarity with the activity [78].

The form of the built environment can also significantly affect mobility among older adults. Many modern cities are designed for vehicles rather than human mobility [116,117], leading to problems of urban sprawl and community severance. The former produces a dispersion of services and activities beyond a reasonable walking and cycling distance [2], the latter a divisive effect on residential areas [118]. Crossing the road in later life is particularly affected by community severance and road traffic issues, due to traffic volumes, speed, noise and pollutant emissions $[48,55,62,77,79,87]$. Asher et al. (2012) found that $84 \%$ of older men and $93 \%$ of older women were not able to cross streets safely as their walking speed was not fast enough to cross the road in time. A similar result was found in both Amosun, Burgess, Groeneveldt and Hodgson [48] and Loo and Tsui [75]. The design of pedestrian/cycling environments was also identified as a barrier for walking and cycling. Poor quality of footpaths, (size, width and presence of steps), broken or uneven pavements, lack of footpath networks and resting places (e.g., benches), toilets in public spaces, cars and scooter parked on, or obstructing, sidewalks and shared walking/cycling environments were found to be the most reported issues $[2,38,55,56,58,67,71,73,74,77-79,119]$. In this sense, an additional barrier found in studies from Northern countries is the presence of snow or ice along the pathway during the winter season [64]. The presence of obstacles and cleanliness of footpaths were found to be associated with problems in obstacle negotiation and the risk of falling. Under such conditions, older pedestrians reported reducing their walking speed, keeping a large distance between them and other pedestrians and spending more time looking at their footsteps rather than straight ahead [76].

As previously discussed for public transport, older people tend to be sensitive about their safety and personal security. Walking and cycling during particular times, such as during the night, or in some less salubrious areas of cities are perceived as dangerous $[67,78,79]$. A lack of adequate street lighting, the presence of dark areas as well as of people, either groups or individuals, "hanging out" are also seen as a deterrent to walking or cycling [73]. Older pedestrians and cyclists are considered vulnerable road users and have the highest rates of fatal and serious casualties. This is generally related to the fact that while ageing, their walking speed reduce, and their decision-making is impaired due to cognitive problems $[2,62,87]$. The safety of older pedestrians and cyclists is also compromised by fear of sharing roads with car users. Apart from the fear of being involved in accidents, older people complain about the behavior of other road users [77]. Oxley, Corben, Fildes and Charlton [117] highlight the fact that roads are mainly designed for car traffic and driver attitudes fail to acknowledge the rights of other users. Older cyclists report feeling safer on quiet roads or on cycle lanes separated from the road in order to avoid accidents, especially those related to car doors opening [66,74,78,80]. Another reported concern was found to be the lack of respect of road rules, not only from drivers, but also from other cyclists and pedestrians, especially younger ones [74,78]. Continuity of cycle lanes and footpaths and problems of mutual space invasion between pedestrians and cyclists, and the speed of other cyclists were also found to be of concern $[38,58,74,78,80]$. Interestingly, the fear of falling off a bicycle was not found to be a safety issue [66].

\section{Discussion and Future Research Agenda}

The importance of access to the car among the older population has been recognized as necessary to fulfil travel needs in later life, due to its flexibility, availability and associated independence. The purpose of this scoping review was to identify the transport barriers affecting the use of alternative 
options to the car among older people. Encouraging the use of alternative transport modes to reduce car usage through a variety of sanctions and incentives are a feature of transport policy in many countries. However if alternative modes to the car are not regarded as valid options, government attempts to reduce car usage are at odds with policies aiming at improvements in independence and quality of life in later years [112]. Furthermore, demographic trends show that within the next two decades the older population will be a more significant demographic group in western countries and consequently require attention to its transport needs. Consequently, research is needed to identify solutions aimed at reducing the gap between the car and its alternatives and creating a transport system that is less dependent on the car, more environmentally-friendly and more able to satisfy older people's mobility needs. The following short and long-term measures are identified based on the main barriers highlighted in the previous section, with the aim of reducing these gaps. As previously mentioned, the older population is characterized by a significant heterogeneity. Therefore, some of the following interventions might suit some groups of older people (e.g., those with health/mobility impairments) more than others.

Short terms measures comprise firstly of training schemes for both public transport staff and users. The role of the bus driver was found to be significant in public transport usage and therefore measures are required to provide services with friendly and helpful bus drivers. In this sense, training should be aimed at enhancing age awareness by valuing the needs and perspectives of older people, as well as on how to provide useful information or operational behavior while driving (e.g., stopping close to the curb to facilitate boarding/alighting; checking if older people are seated before departing or avoid sudden accelerating or breaking). Similarly, on-board staff and front- desk staff should be trained in this sense, particularly for information issues. Training schemes could be provided not only for staff, but for users as well. Service providers and operators, as well as local transport authorities, could run training sessions for older people on how to use public transport. Specific training could be aimed at preventing accidents, on how to behave on-board (e.g., how to safely board or alight, stand and sit) and understanding information related to the journey, both on-board and at stops/stations.

An additional measure to understand older people's needs is to investigate directly with them potential barriers. In this sense, older people might be involved by local transport authorities and service providers in participatory sessions (e.g., round-table workshops), to understand directly their points of view not only in terms of problems and barriers faced, but also with regard to suggestions for planning, service provision and design issues. At the same time, these participatory sessions might be used by local transport authorities and service providers to enhance awareness regarding the role and the advantages of using public transport in later life in terms of independence and overall out-of-home mobility.

Looking at accessibility issues, the distance to reach a bus stop was found to be a recurrent barrier to public transport usage, and consequently measures to better locate stops close to home and destinations are necessary. Similarly, a more user-friendly infrastructure is needed to improve accessibility within the walking environment. In this sense, micro-scale urban design solutions targeting the improvement of walking, such as removals of obstacles, high steps or curbstones and the increase of benches and toilet services can be undertaken to address such issues. This might be particularly effective in the proximity of bus stops and stations. Moreover, monitoring activities can be adopted to identify existing obstacles. Again, active participation from users might be useful to facilitate these types of interventions. Likewise, better design solutions can be adopted to re-think the characteristics of the bus shelter, by allowing more complete shelter from adverse weather (e.g., enclosed structure), and at the same time granting more comfort, visibility and better information about service and routes available. With regard to the latter, as highlighted by Broome, Worrall, Fleming and Boldy [57], it is important to provide information at all stages of the trip. Maps and timetables at stops or stations have to be provided with adequate font size and appropriately contrasting colors, in order to be easily understood by the older population. On-board information also has to be provided along the complete journey with audio and visual details (e.g., on monitors) 
about current position, stops and potential interconnections at stops with other transport services or facilities available [57]. Finally, measures to raise older people's awareness about available services by locating timetables and maps in places frequented traditionally by the older population, such as churches, ageing and community centers, doctor's surgeries and other medical institutions and shopping malls [33].

Longer term changes consist mainly of providing user-friendly design solutions for transport modes and integrated transport networks. With regard to the former, significant improvements have been achieved with the introduction of low-floor, kneeling and ramp-assisted technologies in order to reduce boarding/alighting operations. Nonetheless other design measures can be carried out to improve older people's accessibility and usability, particularly for buses. Interventions needing to be targeted consist of improving on-board conditions, such as standing and moving spaces during the journey. Solutions aimed at re-thinking seat disposition and number and dimensions of the aisle might improve the lack of personal space and also the shortage of space for personal loads. Moreover, actions to re-design the positions and number of handrails could reduce the hindrance to those older passengers lacking arm strength or mobility.

With regard to the latter, it was previously mentioned that the way public transport is provided needs to be improved in several aspects in order to encourage change in current patterns of use. A key issue in this sense is related to the gap in performances related to the car, with flexibility for all. Integration with FTS may provide such a solution, due to its characteristics. The markets that FTS operators need to target in order to make them a viable alternative to private vehicles are those related to local, suburb-to-suburb and peripheral trips (in some places poorly served by public transport) and trips during off-peak times and at night (reduced or stopped service) and more in general those unwilling to use mainstream public transport services [106]. These services need to be responsive to user demands, convenient, have high availability and the ability to transport customers as close as possible to desired destinations. Only if it is included in appropriate transport policies and frameworks can FTS become more efficient and overcome the main barriers preventing its use. At the same time, integrating FTS within the public transport network might be the solution to achieve financial sustainability for these services [106]. In this respect it might be interesting to understand the real impact of potential use of taxis within this context. Using taxis to provide FTS could reduce operational costs and maximize the use of existing resources, with consequent increased availability of service provision. Moreover, unlike other FTS modes (e.g., minibuses), the use of taxis to provide FTS might reduce or nullify the perceived stigma associated with using these transport modes $[60,113]$.

The advent of new transport options related to the improvements of ICT, such as dynamic car-sharing services (e.g., Car2Go, DriveNow and Zipcar), dynamic ridesharing services (e.g., BlaBlaCar and Flinc), peer-to-peer transport schemes (e.g., Uber and Lift) if integrated in the transport network, could also help with this process in the near future [120]. Ambrosino, Nelson, Boero and Ramazzotti [120] highlighted how the concept of a shared mobility service agency might be able to produce a new form of transport service provision for individual and collective transport that might address both the overall service accessibility and the environmental implication of transportation. These modes can potentially represent a more suitable option compared to taxis, since they are characterized by being usually cheaper and providing reduced booking and waiting times. This might help to reduce the gap with private vehicles especially in relation to spontaneous trips for leisure activities. Moreover, helpful features such as background information about the driver and car, fare estimation and split fare options might help overcome issues related to taxi service provision. Very little research has investigated ridesharing among the older population. Research about usage trends and how service providers could target older people as customers, especially from the technological point of view, might lead to new opportunities for mobility in later life. This might show particularly interesting results considering that the next generation of older people is likely to be more accustomed to technology than the current one. 
The development of the so-called Autonomous Vehicles (AV's) might add a further option in this sense. AV's can be defined as those vehicles in which direct control by the driver is not required due to the self-driving characteristics of the vehicle [121]. In spite of the implications associated with potential increases in travel demand, especially from an environmental point of view, AV's technology offers the possibility to create a revolution in the transport system [122,123]. Potential advantages in this sense are those related to improvements in route operations, with consequent reductions in traffic congestion, fuel emission, cost and driving stress; improved road safety and the opportunity to engage with other activities while travelling. Moreover, AV's are likely to increase transport access to unserved populations such as older people, disabled and more generally the non-driving population [123-126]. As advocated by Burns [127], AV's has the potential for the development of a system based on better connected, coordinated, shared, driverless, electric and tailored vehicles. AV's can offer the opportunity to accommodate a new travel demand by offering a more accessible transport option. With regard to older people, a key element to investigate in future research is their potential attitudes and perception towards driverless technology. Despite potential safety benefits of in-vehicle safety technologies (e.g., warning collision/mitigation, parking assist, navigation assistance), older people might find difficulties in adapting to a new way of transportation highly based on technology. Shergold, et al. [128] found in their review that older people are open to new technologies increasing their safety, but less so with regard to the concept of AV's. In this sense older people were found to be less likely to embrace driverless cars compared to younger generations, to be concerned about the lack of control of the car and about the implications of learning how to use a new transport mode at an advanced age.

Author Contributions: C.L. wrote the major parts of the paper. M.T. and M.B. contributed with reviewing, editing and supervising the paper.

Conflicts of Interest: The authors declare no conflict of interest.

\section{References}

1. Lanzieri, G. The greying of the baby boomers. European Commission, 2011. Available online: http:/ / learneurope.eu/files/8413/7525/7795/Envejecimiento_de_la_poblacin_europea_cien_aos_vista.PDF (accessed on 9 June 2018).

2. OECD. Ageing and Transport-Mobility Needs and Safety Issues; OECD: Paris, France, 2001.

3. Banister, D.; Bowling, A. Quality of life for the elderly: The transport dimension. Transp. Policy 2004, 11, 105-115. [CrossRef]

4. Farquhar, M. Elderly people's definitions of quality of life. Soc. Sci. Med. 1995, 41, 1439-1446. [CrossRef]

5. Gilhooly, M.; Hamilton, K.; O’Neill, M.; Gow, J.; Webster, N.; Pike, F.; Bainbridge, D. Transport and Ageing: Extending Quality of Life for Older People via Public and Private Transport; OAI: Chicago, IL, USA, 2002.

6. Metz, D. Mobility of older people and their quality of life. Transp. Policy 2000, 7, 149-152. [CrossRef]

7. Lawton, M.P.; Brody, E.M. Assessment of older people: Self-maintaining and instrumental activities of daily living. Gerontologist 1969, 9, 179-185. [CrossRef] [PubMed]

8. Alsnih, R.; Hensher, D.A. The mobility and accessibility expectations of seniors in an aging population. Transp. Res. Part A 2003, 37, 903-916. [CrossRef]

9. Haustein, S.; Siren, A.; Framke, E.; Bell, D.; Pokriefke, E.; Alauzet, A.; Marin-Lamellet, C.; Armoogum, J.; O'Neill, D. Demographic Change and Transport; European Commission: Brussels, Belgium, 2013.

10. Hildebrand, E.D. Dimensions in elderly travel behaviour: A simplified activity-based model using lifestyle clusters. Transportation 2003, 30, 285-306. [CrossRef]

11. Haustein, S. Mobility behavior of the elderly: An attitude-based segmentation approach for a heterogeneous target group. Transportation 2012, 39, 1079-1103. [CrossRef]

12. Rudinger, G.; Käser, U. Smart modes: Senioren als fussgaenger und radfahrer im kontext alterstypischer aktivitaetsmuster/smart modes-walking and cycling: Typical activity patterns of senior citizens. Z. Verkehrssich. 2007, 53, 141-145. 
13. Aigner-Breuss, E.; Braun, E.; Herry, M.; Steinacher, I.; Sedlacek, N.; Hauger, G.; Klamer, M.; Kriks, S. Mobilitätsszenarienkatalog. Mobilitätszukunft für die Generation 55+. Mobilitätsszenarien für eine Aktive Teilnahme am Verkehr unter Berücksichtigung der Erforderlichen Verkehrstechnologien; IVS-SCHRIFTEN: Wien, Germany, 2011.

14. Mollenkopf, H.; Marcellini, F.; Ruoppila, I.; Széman, Z.; Tacken, M.; Wahl, H.-W. Social and behavioural science perspectives on out-of-home mobility in later life: Findings from the european project mobilate. Eur. J. Ageing 2004, 1, 45-53. [CrossRef] [PubMed]

15. Haustein, S.; Kemming, H. Subjektive sicherheit von senioren im strassenverkehr/perceived danger in road traffic by seniors. Z. Verkehrssich. 2008, 54, 128-133.

16. Haustein, S.; Siren, A. Older people's mobility: Segments, factors, trends. Transp. Rev. 2015, 35, 466-487. [CrossRef]

17. Bell, D.; Pokriefke, E.; Risser, R. Mobility patterns in the ageing populations. 2013. Available online: https:// www.researchgate.net/profile/Aline_Alauzet/publication/274706875_Mobility_Patterns_in_the_Ageing Populations/links/55267b4a0cf2ee9bad77edcd/Mobility-Patterns-in-the-Ageing-Populations.pdf (accessed on 9 June 2018).

18. Glasgow, N.; Blakely, R.M. Older nonmetropolitan residents' evaluations of their transportation arrangements. J. Appl. Gerontol. 2000, 19, 95-116. [CrossRef]

19. Davey, J.A. Older people and transport: Coping without a car. Ageing Soc. 2007, 27, 49-65. [CrossRef]

20. Siren, A.; Hakamies-Blomqvist, L. Private car as the grand equaliser? Demographic factors and mobility in finnish men and women aged 65+. Transp. Res. Part F 2004, 7, 107-118. [CrossRef]

21. Haustein, S.; Siren, A. Seniors' unmet mobility needs - how important is a driving licence? J. Transp. Geogr. 2014, 41, 45-52. [CrossRef]

22. Hjorthol, R. Transport resources, mobility and unmet transport needs in old age. Ageing Soc. 2013, 33, 1190-1211. [CrossRef]

23. Kim, J.-K.; Ulfarsson, G.; Sohn, K. Transportation deficiencies for older adults in seoul, South Korea. Transp. Res. Rec. 2014, 2469, 76-88. [CrossRef]

24. Kim, S. Assessing mobility in an aging society: Personal and built environment factors associated with older people's subjective transportation deficiency in the US. Transp. Res. Part F 2011, 14, 422-429. [CrossRef]

25. Siren, A.; Haustein, S. What are the impacts of giving up the driving licence? Ageing Soc. 2014, 35, 1821-1838. [CrossRef]

26. Luiu, C.; Tight, M.; Burrow, M. The unmet travel needs of the older population: A review of the literature. Transp. Rev. 2017, 37, 488-506. [CrossRef]

27. Luiu, C.; Tight, M.; Burrow, M. A conceptual framework to assess the unmet travel needs in later life. J. Transp. Health 2018. [CrossRef]

28. Evans, E.L. Influences on mobility among non-driving older americans. 2001. Available online: http:/ / onlinepubs.trb.org/Onlinepubs/circulars /EC026/03_evans.pdf (accessed on 9 June 2018).

29. Adler, G.; Rottunda, S. Older adults' perspectives on driving cessation. J. Aging Stud. 2006, 20, $227-235$. [CrossRef]

30. Marottoli, R.A.; Mendes de Leon, C.F.; Glass, T.A.; Williams, C.S.; Cooney, L.M.; Berkman, L.F.; Tinetti, M.E. Driving cessation and increased depressive symptoms: Prospective evidence from the New Haven EPESE. Established populations for epidemiologic studies of the elderly. J. Am. Geriatr. Soc. 1997, 45, $202-206$. [CrossRef] [PubMed]

31. Whitehead, B.J.; Howie, L.; Lovell, R.K. Older people's experience of driver licence cancellation: A phenomenological study. Aust. Occup. Ther. J. 2006, 53, 173-180. [CrossRef]

32. Shergold, I.; Parkhurst, G.; Musselwhite, C. Rural car dependence: An emerging barrier to community activity for older people. Transp. Plan. Technol. 2012, 35, 69-85. [CrossRef]

33. Ward, M.R.; Somerville, P.; Bosworth, G. 'Now without my car I don't know what I'd do': The transportation needs of older people in rural lincolnshire. Local Econ. 2013, 28, 553-566. [CrossRef]

34. Zeitler, E.; Buys, L. Mobility and out-of-home activities of older people living in suburban environments: 'Because I'm a driver, I don't have a problem'. Ageing Soc. 2015, 35, 785-808. [CrossRef]

35. Hanson, T.R.; Hildebrand, E.D. Can rural older drivers meet their needs without a car? Stated adaptation responses from a GPS travel diary survey. Transportation 2011, 38, 975-992. [CrossRef] 
36. Taylor, B.D.; Tripodes, S. The effects of driving cessation on the elderly with dementia and their caregivers. Accid. Anal. Prev. 2001, 33, 519-528. [CrossRef]

37. Rosenbloom, S. Sustainability and automobility among the elderly: An international assessment. Transportation 2001, 28, 375-408. [CrossRef]

38. Rosenbloom, S. Meeting transportation needs in an aging-friendly community. Generations 2009, 33, $33-43$.

39. Mitchell, C.G.B. The licensing and safety of older drivers in Britain. Accid. Anal. Prev. 2013, 50, $732-741$. [CrossRef] [PubMed]

40. Rosenbloom, S. The mobility needs of older Americans. In Taking the High Road: A Transportation Agenda of Strengthening Metropolitan Areas; Katz, B., Puentes, R., Eds.; Brookings Institution Press: Washington, DC, USA, 2004; pp. 227-254.

41. Ahern, A.; Hine, J. Rural transport-valuing the mobility of older people. Res. Transp. Econ. 2012, 34, 27-34. [CrossRef]

42. Tacken, M. Mobility of the elderly in time and space in The Netherlands: An analysis of the Dutch national travel survey. Transportation 1998, 25, 379-393. [CrossRef]

43. Buys, L.; Snow, S.; van Megen, K.; Miller, E. Transportation behaviours of older adults: An investigation into car dependency in urban Australia: Transportation behaviours of older adults. Aust. J. Ageing 2012, 31, 181-186. [CrossRef] [PubMed]

44. Brake, J. Identifying appropriate options for delivering urban transportation to older people. In Urban Transport Xiv: Urban Transport and the Environment in the 21st Century; Brebbia, C.A., Ed.; Wit Press: Southampton, UK, 2008; Volume 101, pp. 57-66.

45. Levac, D.; Colquhoun, H.; O’Brien, K.K. Scoping studies: Advancing the methodology. Implement. Sci. 2010, 5, 69. [CrossRef] [PubMed]

46. Arksey, H.; O'Malley, L. Scoping studies: Towards a methodological framework. Int. J. Soc. Res. Methodol. 2005, 8, 19-32. [CrossRef]

47. Odufuwa, B.O. Enhancing mobility of the elderly in Sub-Saharan Africa cities through improved public transportation. IATSS Res. 2006, 30, 60-66. [CrossRef]

48. Amosun, S.L.; Burgess, T.; Groeneveldt, L.; Hodgson, T. Are elderly pedestrians allowed enough time at pedestrian crossings in Cape Town, South Africa? Physiother. Theory Pract. 2007, 23, 325-332. [CrossRef] [PubMed]

49. Su, F.; Bell, M.G.H. Transport for older people: Characteristics and solutions. Res. Transp. Econ. 2009, 25, 46-55. [CrossRef]

50. Wretstrand, A.; Svensson, H.; Fristedt, S.; Falkmer, T. Older people and local public transit: Mobility effects of accessibility improvements in Sweden. J. Transp. Land Use 2009, 2, 49-65. [CrossRef]

51. Broome, K.; Nalder, E.; Worrall, L.; Boldy, D. Age-friendly buses? A comparison of reported barriers and facilitators to bus use for younger and older adults. Aust. J. Ageing 2010, 29, 33-38. [CrossRef] [PubMed]

52. Broome, K.; Worrall, L.; McKenna, K.; Boldy, D. Priorities for an age-friendly bus system. Can. J. Aging 2010, 29, 435-444. [CrossRef] [PubMed]

53. Chang, H.-L.; Wu, S.-C. Applying the rasch measurement to explore elderly passengers' abilities and difficulties when using buses in Taipei. J. Adv. Transp. 2010, 44, 134-149. [CrossRef]

54. Mattson, J. Aging and mobility in rural and small urban areas: A survey of North Dakota. J. Appl. Gerontol. 2010, 30, 700-718. [CrossRef] [PubMed]

55. Rantakokko, M.; Iwarsson, S.; Hirvensalo, M.; Leinonen, R.; Heikkinen, E.; Rantanen, T. Unmet physical activity need in old age. J. Am. Geriatr. Soc. 2010, 58, 707-712. [CrossRef] [PubMed]

56. Risser, R.; Haindl, G.; Ståhl, A. Barriers to senior citizens' outdoor mobility in Europe. Eur. J. Ageing 2010, 7, 69-80. [CrossRef] [PubMed]

57. Broome, K.; Worrall, L.; Fleming, J.; Boldy, D. Characteristics of age-friendly bus information. J. Public Transp. 2011, 14, 43-61. [CrossRef]

58. Vine, D.; Buys, L.; Aird, R. Experiences of neighbourhood walkability among older Australians living in high density inner-city areas. Plan. Theory Pract. 2012, 13, 421-444. [CrossRef]

59. Brake, J.; Nelson, J.D.; Wright, S. Demand responsive transport: Towards the emergence of a new market segment. J. Transp. Geogr. 2004, 12, 323-337. [CrossRef] 
60. Mulley, C.; Nelson, J.; Teal, R.; Wright, S.; Daniels, R. Barriers to implementing flexible transport services: An international comparison of the experiences in Australia, Europe and USA. Res. Transp. Bus. Manag. 2012, 3, 3-11. [CrossRef]

61. Broome, K.; Worrall, L.; Fleming, J.; Boldy, D. Evaluation of flexible route bus transport for older people. Transp. Policy 2012, 21, 85-91. [CrossRef]

62. Asher, L.; Aresu, M.; Falaschetti, E.; Mindell, J. Most older pedestrians are unable to cross the road in time: A cross-sectional study. Age Ageing 2012, 41, 690-694. [CrossRef] [PubMed]

63. Broome, K.; Worrall, L.; Fleming, J.; Boldy, D. Evaluation of age-friendly guidelines for public buses. Transp. Res. Part A Policy Pract. 2013, 53, 68-80. [CrossRef]

64. Hjorthol, R. Winter weather-An obstacle to older people's activities? J. Transp. Geogr. 2013, 28, $186-191$. [CrossRef]

65. Daniels, R.; Mulley, C. Flexible transport services: Overcoming barriers to implementation in low-density urban areas. Urban Policy Res. 2012, 30, 59-76. [CrossRef]

66. Zander, A.; Passmore, E.; Mason, C.; Rissel, C. Joy, exercise, enjoyment, getting out: A qualitative study of older people's experience of cycling in Sydney, Australia. J. Environ. Public Health 2013, 2013, 547453. [CrossRef] [PubMed]

67. Eronen, J.; von Bonsdorff, M.B.; Törmäkangas, T.; Rantakokko, M.; Portegijs, E.; Viljanen, A.; Rantanen, T. Barriers to outdoor physical activity and unmet physical activity need in older adults. Prev. Med. 2014, 67, 106-111. [CrossRef] [PubMed]

68. Ipingbemi, O. Travel characteristics and mobility constraints of the elderly in Ibadan, Nigeria. J. Transp. Geogr. 2010, 18, 285-291. [CrossRef]

69. Olawole, M.O.; Aloba, O. Mobility characteristics of the elderly and their associated level of satisfaction with transport services in Osogbo, southwestern Nigeria. Transp. Policy 2014, 35, 105-116. [CrossRef]

70. Shiau, T.-A.; Huang, W.-K. User perspective of age-friendly transportation: A case study of Taipei city. Transp. Policy 2014, 36, 184-191. [CrossRef]

71. Chen, Y.J.; Matsuoka, R.H.; Tsai, K.C. Spatial measurement of mobility barriers: Improving the environment of community-dwelling older adults in Taiwan. J. Aging Phys. Act. 2015, 23, 286-297. [CrossRef] [PubMed]

72. Shergold, I.; Lyons, G.; Hubers, C. Future mobility in an ageing society-Where are we heading? J. Transp. Health 2015, 2, 86-94. [CrossRef]

73. Mitra, R.; Siva, H.; Kehler, M. Walk-friendly suburbs for older adults? Exploring the enablers and barriers to walking in a large suburban municipality in Canada. J. Aging Stud. 2015, 35, 10-19. [CrossRef] [PubMed]

74. Winters, M.; Sims-Gould, J.; Franke, T.; McKay, H. “I grew up on a bike”: Cycling and older adults. J. Transp. Health 2015, 2, 58-67. [CrossRef]

75. Loo, B.P.Y.; Tsui, K.L. Contributory factors to critically wrong road-crossing judgments among older people: An integrated research study. Hong Kong J. Emergency Med. 2016, 23, 13. [CrossRef]

76. Tournier, I.; Dommes, A.; Cavallo, V. Review of safety and mobility issues among older pedestrians. Accid. Anal. Prev. 2016, 91, 24-35. [CrossRef] [PubMed]

77. Ramachandran, M.; D'Souza, S.A. A cross-sectional survey on older adults' community mobility in an Indian metropolis. J. Cross Cult. Gerontol. 2016, 31, 19-33. [CrossRef] [PubMed]

78. Ryan, J.; Svensson, H.; Rosenkvist, J.; Schmidt, S.M.; Wretstrand, A. Cycling and cycling cessation in later life: Findings from the city of Malmö. J. Transp. Health 2016, 3, 38-47. [CrossRef]

79. Wang, Y.; Chau, C.K.; Ng, W.Y.; Leung, T.M. A review on the effects of physical built environment attributes on enhancing walking and cycling activity levels within residential neighborhoods. Cities 2016, 50, 1-15. [CrossRef]

80. Velasco, L.; Rojo, M.; Gonzalo-Orden, H.; Diez, J.M. Safety issues with elderly cyclists and barriers to cycling. Proc. Inst. Civil Eng. Munic. Eng. 2015, 168, 87-95. [CrossRef]

81. Atkins, W.S. Older People: Their Transport Needs and Requirements. Department of Transport, Local Government and the Regions, 2001. Available online: https://trid.trb.org/view/1155131 (accessed on 9 June 2018).

82. Harris, A.; Tapsas, D. Transport and Mobility: Challenges, Innovations and Improvements; Royal Automobile Club of Victoria (RACV) Ltd.: Noble Park North, Australia, 2006; pp. 38-43.

83. Knight, T.; Dixon, J.; Warrener, M.; Webster, S. Understanding the Travel Needs, Behaviour and Aspirations of People in Later Life; NatCen: Edinburgh, UK, 2007. 
84. Fiedler, M. Older People and Public Transport; European Metropolitan Transport Authorities: Köln, Germany, 2007.

85. Peck, M.D. Barriers to Using Fixed-Route Public Transit for Older Adults; Mineta Transportation Institute: San Jose, CA, USA, 2010.

86. National Center on Senior Transportation (NCST). Taxis for Senior Transportation; National Center on Senior Transportation: Washington, DC, USA, 2011.

87. Mindell, J.; Rutter, H.; Watkins, S. Urban transportation and human health. In Encyclopedia of Environmental Health; Nriagu, J.O., Ed.; Elsevier: Burlington, NJ, USA, 2011; pp. 578-589.

88. Aceves-Gonzalez, C.; Cook, S.; May, A. Improving bus travel through inclusive design service. In Ergonomics in Design: Methods and Techniques; Soares, M., Rebelo, F., Eds.; CRC Press: Boca Raton, FL, USA, 2016.

89. European Commission. Flash eurobarometer 312 (future of transport). In GESIS Data Archive, Cologne. ZA5472 Data File Version 1.0.0; The GALLUP Organisation: Brussels, Belgium, 2011.

90. Currie, G.; Delbosc, A. Exploring public transport usage trends in an ageing population. Transportation 2010, 37, 151-164. [CrossRef]

91. Beirão, G.; Sarsfield Cabral, J.A. Understanding attitudes towards public transport and private car: A qualitative study. Trans. Policy 2007, 14, 478-489. [CrossRef]

92. Gatersleben, B.; Uzzell, D. Affective appraisals of the daily commute comparing perceptions of drivers, cyclists, walkers, and users of public transport. Environ. Behav. 2007, 39, 416-431. [CrossRef]

93. McKnight, A.J. The freedom of the open road: Driving and older adults. Generations 2003, 27, $25-31$.

94. Brake, J.; Nelson, J.D. A case study of flexible solutions to transport demand in a deregulated environment. J. Transp. Geogr. 2007, 15, 262-273. [CrossRef]

95. Enoch, M.; Potter, S.; Parkhurst, G.; Smith, M. Intermode: Innovations in Demand Responsive Transport; Department for Transport: London, UK, 2004.

96. Mohring, H. The peak load problem with increasing returns and pricing constraints. Am. Econ. Rev. 1970, 60, 693-705.

97. Bar-Yosef, A.; Martens, K.; Benenson, I. A model of the vicious cycle of a bus line. Transp. Res. Part B 2013, 54, 37-50. [CrossRef]

98. Mattson, J. Transportation, distance, and health care utilization for older adults in rural and small urban areas. Transp. Res. Rec. 2011, 2265, 192-199. [CrossRef]

99. Siren, A.; Hjorthol, R.; Levin, L. Different types of out-of-home activities and well-being amongst urban residing old persons with mobility impediments. J. Transp. Health 2015, 2, 14-21. [CrossRef]

100. Musselwhite, C.; Haddad, H. Mobility, accessibility and quality of later life. Qual. Ageing Older Adults 2010, 11, 25-37. [CrossRef]

101. Nordbakke, S. Capabilities for mobility among urban older women: Barriers, strategies and options. J. Transp. Geogr. 2013, 26, 166-174. [CrossRef]

102. Carlsson, G. Catching the Bus in Old Age-Methodological Aspects of Accessibility Assessments in Public Transport; Division of Occupational Therapy: Lund, Sweden, 2002.

103. Aceves-Gonzalez, C. The Application and Development of Inclusive Service Design in the Context of a Bus Service. Ph.D. Thesis, Loughborough University, Loughborough, UK, November 2014.

104. Haustein, S.; Møller, M. Age and attitude: Changes in cycling patterns of different e-bike user segments. Int. J. Sustain. Transp. 2016, 10, 836-846. [CrossRef]

105. Metz, D. Transport policy for an ageing population. Transp. Rev. 2010, 23, 375-386. [CrossRef]

106. Finn, B. Towards large-scale flexible transport services: A practical perspective from the domain of paratransit. Res. Transp. Bus. Manag. 2012, 3, 39-49. [CrossRef]

107. Nelson, J.D.; Wright, S.; Masson, B.; Ambrosino, G.; Naniopoulos, A. Recent developments in flexible transport services. Res. Transp. Econ. 2010, 29, 243-248. [CrossRef]

108. Currie, G. Quantifying spatial gaps in public transport supply based on social needs. J. Transp. Geogr. 2010, 18, 31-41. [CrossRef]

109. Brake, J.; Mulley, C.; Nelson, J.D.; Wright, S. Key lessons learned from recent experience with flexible transport services. Transp. Policy 2007, 14, 458-466. [CrossRef]

110. Nelson, J.D.; Phonphitakchai, T. An evaluation of the user characteristics of an open access DRT service. Res. Transp. Econ. 2012, 34, 54-65. [CrossRef] 
111. Kim, S. Transportation alternatives of the elderly after driving cessation. Transp. Res. Rec. 2011, 2265, 170-176. [CrossRef]

112. Oxley, P. United Kingdom. In Transport and Ageing of the Population; European Conference of Ministers of Transport: Paris, France, 2000.

113. Trudel, M. Taxis: An Omnipresent Resource for Transporting People with Reduced Mobility; International Conference on Taxi Regulation: Montreal, QC, Canada, 1992.

114. Jones, T.; Pooley, C.G.; Scheldeman, G.; Horton, D.; Tight, M.; Mullen, C.; Jopson, A.; Whiteing, A. Moving around the city: Discourses on walking and cycling in English urban areas. Environ. Plan. A 2012, 44, 1407-1424. [CrossRef]

115. Tight, M. Sustainable urban transport-the role of walking and cycling. In Proceedings of the Institution of Civil Engineers-Engineering Sustainability; Thomas Telford Ltd.: London, UK, 2016; pp. 87-91.

116. Matan, A.; Newman, P. Jan gehl and new visions for walkable Australian cities. World Transp. Policy Pract. 2012, 17, 30-41.

117. Oxley, J.; Corben, B.; Fildes, B.; Charlton, J. Older pedestrians: Meeting their safety and mobility needs. In Proceedings of the Road Safety Research, Policing and Education Conference, Perth, Australia, 14-16 November 2004; Road Safety Council of Western Australia: Perth, Australia, 2004.

118. Mindell, J.S.; Karlsen, S. Community severance and health: What do we actually know? J. Urban Health 2012, 89, 232-246. [CrossRef] [PubMed]

119. Mattson, J. Travel Behavior and Mobility of Transportation-Disadvantaged Populations: Evidence from the National Household Travel Survey; Upper Great Plains Transportation Institute: Fargo, ND, USA, 2012.

120. Ambrosino, G.; Nelson, J.D.; Boero, M.; Ramazzotti, D. From the concept of flexible mobility services to the 'shared mobility services agency'. In Paratransit: Shaping the Flexible Transport Future; Emerald Group Publishing Limited: Bingley, UK, 2016; pp. 203-215.

121. NHTSA. U.S. Department of Transportation Releases Policy on Automated Vehicle Development. National Highway Traffic Safety Administration; NHTSA: Washington, DC, USA, 2013.

122. Nielsen, T.A.S.; Haustein, S. On sceptics and enthusiasts: What are the expectations towards self-driving cars? Transp. Policy 2018, 66, 49-55. [CrossRef]

123. Thomopoulos, N.; Givoni, M. The autonomous car-A blessing or a curse for the future of low carbon mobility? An exploration of likely vs. Desirable outcomes. Eur. J. Futures Res. 2015, 3, 14. [CrossRef]

124. Anderson, J.M.; Nidhi, K.; Stanley, K.D.; Sorensen, P.; Samaras, C.; Oluwatola, O.A. Autonomous Vehicle Technology: A Guide for Policymakers; Rand Corporation: Santa Monica, CA, USA, 2014.

125. Clark, B.; Parkhurst, G.; Ricci, M. Understanding the Socioeconomic Adoption Scenarios for Autonomous Vehicles: A Literature Review; University of the West of England: Bristol, UK, 2016.

126. Harper, C.D.; Hendrickson, C.T.; Mangones, S.; Samaras, C. Estimating potential increases in travel with autonomous vehicles for the non-driving, elderly and people with travel-restrictive medical conditions. Transp. Res. Part C Emerg. Technol. 2016, 72, 1-9. [CrossRef]

127. Burns, L.D. Sustainable mobility: A vision of our transport future. Nature 2013, 497, 181-182. [CrossRef] [PubMed]

128. Shergold, I.; Wilson, M.; Parkhurst, G. The Mobility of Older People, and the Future Role of Connected Autonomous Vehicles. Project Report; Centre for Transport and Society, University of the West of England: Bristol, UK, 2016.

(C) 2018 by the authors. Licensee MDPI, Basel, Switzerland. This article is an open access article distributed under the terms and conditions of the Creative Commons Attribution (CC BY) license (http:/ / creativecommons.org/licenses/by/4.0/). 